\title{
Postharvest quality and shelf life of Passiflora cincinnata BRS Sertão Forte fruits according to type of fertilization and storage
}

\author{
Maria Madalena Rinaldi ${ }^{1}$, Ana Maria Costa $^{2}$, Juaci Vitória Malaquias ${ }^{3}$, Eder de Souza Martins ${ }^{4}$
}

\begin{abstract}
The present study aimed to evaluate the physicochemical characteristics and shelf life of $P$. cincinnata BRS Sertão Forte fruits produced with conventional fertilization recommended for passion fruit, conventional organic fertilization, organic fertilization enriched with biotite schist, conventional fertilization with replacement of the potassium source and chemical fertilization only and the mineral nutrition of plants stored under ambient and refrigerated conditions. Analyses of $\mathrm{pH}$, soluble solids, titratable acidity, ratio, color, texture and mass loss were performed. Fertilizers differed in terms of nutrient absorption associated with protein synthesis $(\mathrm{N}, \mathrm{S}, \mathrm{B}, \mathrm{Cu}, \mathrm{Mn}, \mathrm{Zn})$, especially where soil remineralizer was applied. Treatments without fertilization and that with organic fertilization enriched with biotite schist soil remineralizer also positively influenced fruit physicochemical properties such as color and texture. Fruits stored under refrigeration conditions showed the best results for the conservation of their qualitative characteristics. Under the conditions of the present study, it could be concluded that the postharvest life of $P$. cincinnata fruits stored under refrigeration at $10^{\circ} \mathrm{C}$ is at least 60 days. This period is 30 days under ambient conditions.
\end{abstract}

Index terms: passion fruit, conservation, storage, color.

Corresponding author: madalena.rinaldi@ embrapa.br

Received: June 04, 21 Accepted: October 08, 21

Copyright: All the contents of this journal, except where otherwise noted, is licensed under a Creative Commons Attribution License.

(cc) EY

\section{Qualidade pós-colheita e vida útil de frutos de Passiflora cincinnata BRS Sertão Forte em função do tipo de adubação e armazenamento}

\begin{abstract}
Resumo- O presente trabalho avaliou o efeito da adubação convencional para o maracujazeiro, adubação orgânica convencional, adubação orgânica enriquecida com biotita xisto, adubação convencional com substituição da fonte potássica e somente adubação química, na nutrição mineral da planta, na produção, nas características físico-químicas e na vida útil dos frutos de $P$. cincinnata cultivar BRS Sertão Forte armazenados sob condição ambiente e refrigerada. Determinaram-se os nutrientes minerais do solo e das folhas, o número e a massa total de frutos, o pH, os sólidos solúveis, a acidez titulável, Ratio, a coloração, a textura e a perda de massa. As adubações diferiram quanto à absorção de nutrientes associados à síntese de proteínas (N, S, B, Cu, Mn e Zn), especialmente onde o remineralizador foi aplicado. Os tratamentos sem adubação e o com adubação orgânica enriquecida com remineralizador de solos biotita xisto também influenciaram positivamente nas propriedades físico-químicas de coloração e de textura dos frutos. Os frutos armazenados sob condição refrigerada apresentaram os melhores resultados de conservação de suas características qualitativas. Nas condições do presente trabalho, pode-se afirmar que a vida útil pós-colheita dos frutos de $P$. cincinnata armazenados sob refrigeração a $10^{\circ} \mathrm{C}$, é de, no mínimo, 60 dias. Em condição ambiente, este período é de, no máximo 30 dias.
\end{abstract}

Termos para indexação: maracujá, conservação, armazenamento, cor. 


\section{Introduction}

Passiflora cincinnata Mast. known as wild passion fruit is a species with wide distribution in Brazil, particularly in the Caatinga and Cerrado biomes, being a perennial plant, resistant to drought, growing in different types of soil under natural conditions (ARAÚJO et al., 2019). Fruits, usually obtained from extractivism, have become popular in the market for their characteristic flavor and aroma, being appropriate for the preparation of juices and jellies (CARMO et al., 2017). The pulp has phytochemical composition that indicates its potential as a functional food, which aroused great interest in studies aiming at its diversified use (SIEBRA et al., 2016). The processed product, in the form of jelly, has already been exported to Germany and Italy (KILL et al., 2010).

In 2016, Embrapa launched the BRS Sertão Forte (BRS SF) (Embrapa 2020), a hybrid cultivar resulting from the crossing of two populations independently obtained, selected for fruit quality and yield (ARAÚJO et al., 2019). The cultivar met the wishes of small farmers for cultivation under rainfed conditions, considering the tolerance of the species to water stress (SANTOS et al., 2016). This cultivar was developed for semiarid and Cerrado conditions. Since its launch in 2016, it has been cultivated and marketed by farmers from these two Brazilian regions.

In general, the semiarid and Cerrado regions have climatic conditions favorable for the cultivation of $P$. cincinnata due to its perennial nature and drought resistance. In the semiarid region, the cultivar presents perennial behavior and good productivity (ARAÚJO et al., 2019). However, in crops monitored by Embrapa Cerrados in the DF region and surroundings, the plant has presented annual production cycle with early plant death at the end of the first fruiting cycle. The situation suggests possible plant depletion as a result of inadequate fertilization.

Fertilizers used in BRS SF crops in the DF region and surrounding areas are based on the recommendation of Resende et al. (2008) for passion fruit, Passiflora edulis Sims, except for the non-use of limestone in the preparation of pits. In organic crops, producers reported using only tanned bovine manure, with nitrogen content equivalent to that recommended by Resende et al., (2008).

The use of soil remineralizers has increased in organic crops due to their potential to improve the efficiency of nutrient use by crops, with remineralizer derived from biotite schist being a natural potassium source and other nutrients considered important for passion fruit cultivation (RESENDE et al., 2006). Regarding postharvest, fruits of several passion fruit species, in general, present conservation difficulties due to their high susceptibility to rot, pulp fermentation and mass loss during the storage period. BRS SF fruits have light green color when ripe, with weight ranging from 109 to $212 \mathrm{~g}$, with very acidic pulp and soluble solids contents ranging from 8 to $13^{\circ}$ Brix (ARAÚJO et al., 2019). Information on the physicochemical characteristics and postharvest conservation of passion fruit, especially of species that are particularly new to the market, allows consumers to know more about the product, and helps producers in the proper storage of fruits.

The storage period of passion fruit can be extended, provided that mechanisms are used to reduce the transpiration and respiration rates of fruits, a situation that can be modulated with the use of adequate packaging, coating fruits with carnauba wax and reducing metabolic activity by reducing the storage temperature (CUNHA et al., 2017). P. cincinnata fruits can be kept in cold chamber at temperature of $10^{\circ} \mathrm{C}$ and relative humidity of $85 \%$ for 98 days. Under ambient temperature and relative humidity conditions, the shelf life of fruits is at most 30 days (RINALDI et al., 2021). The use of refrigeration technology in the conservation of fruits of different passion fruit species such as $P$. setacea, $P$. alata and $P$. edulis is also recommended, since it increases the shelf life of fruits, also preserving several important physiological parameters such as peel texture and color, in addition to reducing infestation by fungal agents (RINALDI et al., 2019a; RINALDI et al., 2019b; RINALDI et al., 2017; ROTILI et al., 2013a; ROTILI et al., 2013b; JUNQUEIRA et al., 2003).

Adequate fertilization provides plants greater productivity, better fruit quality, greater tolerance and resistance to pests and diseases (PIRES et al., 2011; BORGES, 2004). The effects of fertilization on the postharvest fruit quality must be carefully considered, and it is necessary to determine the doses and types of nutrients that result in maximum economic production and better fruit quality (SENHOR et al., 2009). However, there is still no scientific information about the effect of different fertilizations on the postharvest quality of $P$. cincinnata fruits.

In this context, the aim of this study was to evaluate the behavior of Passiflora cincinnata BRS SF cultivar produced in systems with different fertilization, based on chemical and organic fertilization practiced by producers in the DF region and surroundings, and the impact of fertilizations on the physicochemical characteristics and shelf life of fruits stored under ambient and refrigeration conditions.

\section{Material and methods}

The experiment was carried out in the experimental field of Embrapa Cerrados, 15³6'13.02"'S; 4743'17.34" $\mathrm{W}$, and $1050 \mathrm{~m}$ a.s.1, Planaltina - DF, in a dystrophic Red Latosol with clayey texture (45\% clay) (LIMA et al., 2014). Passiflora cincinnata seedlings BRS Sertão Forte cultivar (BRS SF) were transplanted to 3.5-month-old pits. Crops were implemented in December 2016 in vertical shoot positioning system with spacing between plants and between rows of $2.5 \mathrm{~m} \times 2.5 \mathrm{~m}$. Fertilization was carried out in the pit and drip irrigation, with fixed watering shift of two days for a period of one hour, with flow rate of 8 liters per hour calculated based on crop evapotranspiration. 
At the beginning of the experiment, the soil had $\mathrm{pH}$ of 5.3; exchangeable acidity $(\mathrm{H}+\mathrm{Al})$ of $4.3 \mathrm{cmol}_{\mathrm{c}} \mathrm{dm}^{-3}$; $\mathrm{Al}$ $0.3 \mathrm{cmol}_{\mathrm{c}} \mathrm{dm}^{-3}$ and $33 \%$ base saturation.

Treatments were established based on the fertilization practices of producers in DF and surrounding areas in relation to BRS SF cultivation, maintaining the condition of non-use of limestone in the production area. The soil remineralizer used in treatments to promote the best use of nutrients by plants was purchased from company Tratto Agronegócios (brand name of the product: FMX remineralizer). The experiment consisted of six treatments: Control (T1), receiving no fertilization; conventional fertilization recommended for passion fruit based on soil analysis: $20 \mathrm{~L} /$ pit of tanned cattle manure, $248.6 \mathrm{~g} / \mathrm{pit}$ of Single Super Phosphate, $98.8 \mathrm{~g} / \mathrm{pit}$ of ammonium sulfate, $98 \mathrm{~g} /$ pit of potassium chloride and $100 \mathrm{~g} /$ pit of FTE BR12, as recommended by Resende et al. (2008) (T2); Organic fertilization: $80 \mathrm{~L}$ of tanned cattle manure according to the practice of BRS SF producers in DF and surroundings (T3); Organic fertilizer enriched with biotite schist soil remineralizer $\left(3.5 \% \mathrm{~K}_{2} \mathrm{O}\right): 16.6 \mathrm{~kg}$ of biotite schist fertilizer and $20 \mathrm{~L} /$ pit of tanned bovine manure (T4); Conventional fertilization (RESENDE et al., 2008), with replacement of the potassium source by biotite schist soil remineralizer $3.5 \% \mathrm{~K}_{2} \mathrm{O}: 17 \mathrm{~kg}$ of biotite schist soil remineralizer $248 \mathrm{~g} /$ pit of Super Simples, 98 $\mathrm{g} / \mathrm{pit}$ of ammonium sulfate and $100 \mathrm{~g} /$ pit of FTE BR12, which comprises elements in the following proportions: Calcium (Ca): 7.1\%; Sulfur (S): 5.7\%; Boron (B): 1.8\%; Copper (Cu): $0.8 \%$; Manganese (Mn): $2.0 \%$; Molybdenum (Mo): 0.1\%; Zinc (Zn): 9.0\% (T5); Only NPK chemical fertilization (fertilization recommended by Resende et al. (2008), without organic matter and equalized according to the mineral manure composition) and $100 \mathrm{~g} /$ pite of FTE BR12 (T6). At the moment of the fall of first fruits (beginning of production), analyses of the fourth and fifth leaves from the bud at the end of branches and the soil analysis of all treatments were carried out. Leaf and soil analyses were determined by Laboratório Soloquímica Ltda company, DF, according to the standard routine procedure for the determination of elements in leaf and soil.

There was only one collection of all fruits of the same harvest, and fruits were approximately 100 days old from anthesis, with similar maturation stage (D'ABADIA et al., 2020; SANTOS, 2018). Fruits were evaluated at the Laboratory of Food Science and Technology of Embrapa Cerrados. In the laboratory, the counting and determination of the total fruit mass were carried out. Then, fruits were washed in running water with subsequent drying on paper towels and stored under ambient conditions $\left(22^{\circ} \mathrm{C}\right.$ and $70 \%$ relative humidity) and refrigerated $\left(10^{\circ} \mathrm{C}\right.$ and $85 \%$ to $90 \%$ relative humidity) for a period of 60 days.

At time zero, 30 and 60 days of storage, fruits were analyzed for $\mathrm{pH}$, titratable acidity, soluble solids and
SS/TA ratio according to AOAC (2012). The peel color $\left(L^{*}, a^{*}, b^{*}\right)$ was determined in HunterLab MiniScan ${ }^{\circledR}$ EZ spectrophotometer, with five readings per fruit. From L, a*, $\mathrm{b}^{*}$ values, browning increment (IE), chroma and hue angle were obtained as recommended by Hunterlab (2008).

For the texture analysis, the Brookfield Texture Analyzer model CT3 4500, was used. The analysis consisted of the perforation resistance test (normal test), adopting the following trigger patterns (force): $10 \mathrm{~g}$, deformation: $10 \mathrm{~mm}$ and speed: $10 \mathrm{~mm} / \mathrm{s}$ with the aid of TA 17 Cone $30 \mathrm{~mm} \mathrm{D,} 45^{\circ}$ tip. Results were expressed in Newton (N). Fresh mass loss analyses were also carried out, which results were obtained by the difference between the initial mass and the mass at the time of post-storage evaluation.

The experimental design was completely randomized with three replicates with two plants for each fertilization treatment, and fruit longevity evaluations were also carried out in three replicates of 15 fruits in a $2 \times 6$ factorial with two storage and six fertilization forms. The field experiment has a single factor with total of six treatments. For statistical analysis, data were submitted to analysis of variance using the $\mathrm{F}$ test and means were grouped using the Tukey test at 5\% probability. Analysis of variance assumptions were verified using the ShapiroWilk test for error normality and the Bartlett test for variance homogeneity. For variables in which this condition was not met, even after data transformation by $\log (x+0.5)$, the non-parametric Kruskal-Wallis test was applied at 5\% significance level. In order to analyze the correlation of physical and chemical variables and evaluate the joint effect of such variables in two different types of environments (ambient and refrigerated) and three different observation times, the Principal Component Analysis (PCA) multivariate method was used. The "FactoMineR" and "factoextra" packages present in the R statistical software were used. All analyses were performed using the $\mathrm{R}$ statistical software, version 3.5.1 (R Core Team, 2018).

\section{Results and discussion}

The number and mass of fruits did not differ statistically among fertilization treatments (Table 1). Likewise, with some exceptions, the results show that all treatments were statistically identical in terms of nutrient accumulation in plant tissues. There was greater $\mathrm{Ca}$ accumulation in the plant tissues of treatment $\mathrm{T} 1$, which did not receive any source of nutrients or soil conditioner compared to $\mathrm{T} 2, \mathrm{~T} 3$ and $\mathrm{T} 4$, indicating antagonistic behavior to nutrients previously indicated for the conditions of the experiment. Antagonism between $\mathrm{N}$ and $\mathrm{S}$ with $\mathrm{Ca}$ has been reported in other works with passion fruit (MOURA et al., 2017). 
Table 1. Number and mass of fruits per plant and nutrient content present in the leaves of BRS Sertão Forte fruits (Passiflora cincinnata) 100 days after the beginning of production.

\begin{tabular}{|c|c|c|c|c|c|c|}
\hline \multicolumn{7}{|c|}{ Treatments } \\
\hline Variables & 1 & 2 & 3 & 4 & 5 & 6 \\
\hline Nfru & $23 \mathrm{~ns}$ & $29 \mathrm{~ns}$ & $14 \mathrm{~ns}$ & $19 \mathrm{~ns}$ & $29 \mathrm{~ns}$ & $36 \mathrm{~ns}$ \\
\hline$\underline{\operatorname{MFreT}(\mathrm{g})}$ & $2171.70 \mathrm{~ns}$ & $3113.30 \mathrm{~ns}$ & $1296.70 \mathrm{~ns}$ & $1410.00 \mathrm{~ns}$ & $2851.70 \mathrm{~ns}$ & $3495.00 \mathrm{~ns}$ \\
\hline \multicolumn{7}{|c|}{$\mathrm{g} \mathrm{kg}^{-1}$} \\
\hline $\mathrm{N}$ & $26.87 \mathrm{ab}$ & $19.33 \mathrm{~b}$ & $19.57 \mathrm{ab}$ & $23.17 \mathrm{ab}$ & $33.05 \mathrm{a}$ & $32.80 \mathrm{ab}$ \\
\hline $\mathrm{P}$ & $1.33 \mathrm{~ns}$ & $1.59 \mathrm{~ns}$ & $1.84 \mathrm{~ns}$ & $1.89 \mathrm{~ns}$ & $1.99 \mathrm{~ns}$ & $1.77 \mathrm{~ns}$ \\
\hline $\mathrm{K}$ & $21.87 \mathrm{~ns}$ & $26.53 \mathrm{~ns}$ & $30.10 \mathrm{~ns}$ & $28.43 \mathrm{~ns}$ & $29.20 \mathrm{~ns}$ & $20.45 \mathrm{~ns}$ \\
\hline $\mathrm{Ca}$ & $36.27 \mathrm{a}$ & $21.03 \mathrm{~b}$ & $21.27 \mathrm{~b}$ & $21.17 \mathrm{~b}$ & $25.55 \mathrm{ab}$ & $29.10 \mathrm{ab}$ \\
\hline $\mathrm{Mg}^{*}$ & $7.18 \mathrm{~ns}$ & $7.77 \mathrm{~ns}$ & $4.42 \mathrm{~ns}$ & $5.76 \mathrm{~ns}$ & $4.87 \mathrm{~ns}$ & $5.01 \mathrm{~ns}$ \\
\hline$\underline{S}$ & $1.77 \mathrm{~b}$ & $1.89 \mathrm{ab}$ & $1.85 \mathrm{ab}$ & $1.68 \mathrm{~b}$ & $2.43 \mathrm{a}$ & $2.32 \mathrm{ab}$ \\
\hline \multicolumn{7}{|c|}{$\mathrm{mg} \mathrm{kg}^{-1}$} \\
\hline $\mathrm{Fe}$ & $279.67 \mathrm{~ns}$ & $386.33 \mathrm{~ns}$ & $581.33 \mathrm{~ns}$ & $406.67 \mathrm{~ns}$ & $336.00 \mathrm{~ns}$ & $292.50 \mathrm{~ns}$ \\
\hline B* & $3.25 \mathrm{~b}$ & $3.33 \mathrm{~b}$ & $4.43 \mathrm{ab}$ & $4.14 \mathrm{ab}$ & $7.01 \mathrm{a}$ & $4.19 \mathrm{ab}$ \\
\hline $\mathrm{Cu}$ & $1.77 \mathrm{ab}$ & $1.89 \mathrm{ab}$ & $1.85 \mathrm{ab}$ & $1.68 \mathrm{~b}$ & $2.43 \mathrm{a}$ & $2.32 \mathrm{ab}$ \\
\hline $\mathrm{Mn}$ & $129.67 \mathrm{ab}$ & $147.67 \mathrm{ab}$ & $112.33 \mathrm{ab}$ & $153.67 \mathrm{a}$ & $102.70 \mathrm{~b}$ & $115.50 \mathrm{ab}$ \\
\hline $\mathrm{Zn} *$ & $9.42 \mathrm{ab}$ & $8.63 \mathrm{~b}$ & $8.66 \mathrm{~b}$ & $9.77 \mathrm{a}$ & $14.50 \mathrm{a}$ & $6.50 \mathrm{ab}$ \\
\hline
\end{tabular}

Equal lowercase letters on the same line do not differ significantly at 5\% level in the Tukey's test. Number of fruits per plant (Nfru); Total fresh fruit mass per plant (MFreT); Leaf nutrients, nitrogen $(\mathrm{N})$, phosphorus $(\mathrm{P})$, potassium $(\mathrm{K})$, calcium $(\mathrm{Ca})$, magnesium $(\mathrm{Mg})$, sulfur $(\mathrm{S})$, iron $(\mathrm{Fe})$, boron $(\mathrm{B})$, copper $(\mathrm{Cu})$, manganese $(\mathrm{Mn})$, zinc $(\mathrm{Zn})$. *Parameter that did not present normal distribution and the non-parametric Kruskal-Wallis test was used. Treatments: 1: no fertilization; 2: conventional fertilization recommended for passion fruit based on soil analysis; 3: conventional organic fertilization; 4: organic fertilizer enriched with biotite schist; 5: conventional fertilization with replacement of the potassium source; 6: chemical fertilization only.

Soil fertility levels at the beginning of flowering (Table 2) are considered low for most parameters, according to criteria defined by Resende et al. (2008), since the base saturation is below $40 \%$ in all treatments and the sum of $\mathrm{Ca}+\mathrm{Mg}$ is lower than $2.0 \mathrm{cmolc} \mathrm{kg}^{-1}$. Exchangeable $\mathrm{Al}$ is very high for all treatments, with values above $0.3 \mathrm{cmol}_{\mathrm{c}} \mathrm{kg}^{-1}$, typical of Cerrado Oxisols that receive no liming. The $\mathrm{Mg}$ contents in the plant tissue are similar among treatments, but there are important differences in relation to calcium, where the highest values are observed for treatment $\mathrm{T} 1$, which did not receive any fertilization, and intermediate values are observed for treatments $\mathrm{T} 5$ and $\mathrm{T} 6$, which received potassium in the form of remineralizer and $\mathrm{KCl}$, respectively. The lowest values were observed for treatments $\mathrm{T} 2, \mathrm{~T} 3$ and $\mathrm{T} 4$.
$\mathrm{K}$ levels are considered low (lower than $0.7 \mathrm{cmol}_{\mathrm{c}}$ $\mathrm{kg}^{-1}$ ) (RESENDE et al., 2008) for treatments that did not receive fertilization (T1) and those that received fertilization with organic sources (T2 and T3), and adequate for treatments that received soluble sources and/ or soil remineralizer (T4, T5 and T6). However, these differences in soil $\mathrm{K}$ availability did not reflect its uptake by plants, being similar for all treatments (Table 1).

According to Resende et al. (2008), soil P contents are considered low for treatments T1-T5 (lower than 5 $\left.\mathrm{mg} \mathrm{kg}^{-1}\right)$, and intermediate for treatment $\mathrm{T} 6\left(5.3 \mathrm{mg} \mathrm{kg}^{-1}\right)$, which received fertilization with soluble sources. However, $\mathrm{P}$ contents in plant tissues were similar in all treatments (Table 2). The same was observed for B contents, which are also considered low for all treatments (lower than 0.2 $\mathrm{mg} \mathrm{kg}{ }^{-1}$ ), while for the other micronutrients, values are considered very high (RESENDE et al., 2008). Treatments T4, T5 and T6 stand out, with very high Fe (above $200 \mathrm{mg}$ $\mathrm{kg}^{-1}$ ) and $\mathrm{Mn}$ levels (above $30 \mathrm{mg} \mathrm{kg}^{-1}$ ). However, the $\mathrm{Fe}$ uptake by the plant did not differ among treatments, and Mn uptake was correlated with soil availability, especially in treatment $\mathrm{T} 4$, where manure and soil remineralizer were applied. However, the opposite occurred in treatment T5, which, despite the greater soil Mn availability, presented the lowest Mn uptake among treatments. Again, this fact seems to indicate that the soil remineralizer has a nutrient regulation function that should be investigated in future works. 
Table 2. Soil physicochemical characteristics at the beginning of flowering of BRS Sertão Forte cultivar (Passiflora cincinnata).

\begin{tabular}{|c|c|c|c|c|c|c|c|c|c|}
\hline \multirow{2}{*}{ Variables } & \multicolumn{6}{|c|}{ Treatments } & \multicolumn{3}{|c|}{ Soil fertility reference** } \\
\hline & 1 & 2 & 3 & 4 & 5 & 6 & & & \\
\hline \multirow[t]{2}{*}{$\mathrm{pH}$} & $5.30 \mathrm{~ns}$ & $5.30 \mathrm{~ns}$ & $5.40 \mathrm{~ns}$ & $5.30 \mathrm{~ns}$ & $5.60 \mathrm{~ns}$ & $5.20 \mathrm{~ns}$ & $\mathrm{~L}$ & $M$ & A \\
\hline & \multicolumn{9}{|c|}{$\mathrm{cmol} \mathrm{kg}^{-1}$} \\
\hline$\overline{\mathrm{Ca}}$ & $1.30 \mathrm{~ns}$ & $1.30 \mathrm{~ns}$ & $1.60 \mathrm{~ns}$ & $1.30 \mathrm{~ns}$ & $1.60 \mathrm{~ns}$ & $1.60 \mathrm{~ns}$ & $<2$ & - & $>2$ \\
\hline $\mathrm{Mg}$ & $0.40 \mathrm{~ns}$ & $0.60 \mathrm{~ns}$ & $0.50 \mathrm{~ns}$ & $0.60 \mathrm{~ns}$ & $0.60 \mathrm{~ns}$ & $0.50 \mathrm{~ns}$ & $<0.9$ & - & $>0.9$ \\
\hline K & $0.06 \mathrm{~b}$ & $0.05 \mathrm{~b}$ & $0.04 \mathrm{~b}$ & $0.26 \mathrm{ab}$ & $0.42 \mathrm{a}$ & $0.32 \mathrm{a}$ & $<0.06$ & 0.06 to 0.2 & $>0.2$ \\
\hline $\mathrm{Na}$ & $0.02 \mathrm{~b}$ & $0.02 \mathrm{~b}$ & $0.01 \mathrm{~b}$ & $0.09 \mathrm{a}$ & $0.10 \mathrm{a}$ & $0.09 \mathrm{a}$ & nd & nd & nd \\
\hline S & $21.00 \mathrm{~ns}$ & $19.80 \mathrm{~ns}$ & $28.70 \mathrm{~ns}$ & $25.20 \mathrm{~ns}$ & $17.70 \mathrm{~ns}$ & $34.8 \mathrm{~ns}$ & $<20$ & nd & $>20$ \\
\hline $\mathrm{Al}$ & $0.30 \mathrm{~ns}$ & $0.40 \mathrm{~ns}$ & $0.30 \mathrm{~ns}$ & $0.40 \mathrm{~ns}$ & $0.30 \mathrm{~ns}$ & $0.60 \mathrm{~ns}$ & $<0.02$ & 0.02 to 1.5 & $>1.5$ \\
\hline $\mathrm{H}+\mathrm{Al}$ & $4.40 \mathrm{~b}$ & $4.40 \mathrm{~b}$ & $3.80 \mathrm{~b}$ & $4.00 \mathrm{~b}$ & $4.20 \mathrm{~b}$ & $5.20 \mathrm{a}$ & nd & nd & nd \\
\hline $\mathrm{P}\left(\mathrm{mg} \mathrm{kg}^{-1}\right)$ & $3.50 \mathrm{ab}$ & $2.90 \mathrm{~b}$ & $2.10 \mathrm{~b}$ & $4.20 \mathrm{ab}$ & $4.30 \mathrm{ab}$ & $5.30 \mathrm{a}$ & $<5$ & 5 to 8 & $>8$ \\
\hline \multirow[t]{2}{*}{$\mathrm{C}\left(\mathrm{g} \mathrm{kg}^{-1}\right)$} & $10.00 \mathrm{~ns}$ & $9.30 \mathrm{~ns}$ & $10.40 \mathrm{~ns}$ & $9.00 \mathrm{~ns}$ & $11.00 \mathrm{~ns}$ & $9.40 \mathrm{~ns}$ & nd & nd & nd \\
\hline & \multicolumn{9}{|c|}{$\mathrm{cmol}_{\mathrm{c}} \mathrm{kg}^{-1}$} \\
\hline$\overline{\mathrm{SB}}$ & $1.80 \mathrm{~ns}$ & $1.90 \mathrm{~ns}$ & $2.20 \mathrm{~ns}$ & $2.20 \mathrm{~ns}$ & $2.70 \mathrm{~ns}$ & $2.40 \mathrm{~ns}$ & nd & nd & nd \\
\hline CEC & $6.80 \mathrm{~ns}$ & $6.30 \mathrm{~ns}$ & $6.00 \mathrm{~ns}$ & $6.20 \mathrm{~ns}$ & $6.80 \mathrm{~ns}$ & $7.60 \mathrm{~ns}$ & nd & nd & nd \\
\hline \multirow[t]{2}{*}{ V(\%) } & $29.00 \mathrm{~ns}$ & $30.20 \mathrm{~ns}$ & $36.70 \mathrm{~ns}$ & $35.50 \mathrm{~ns}$ & $39.70 \mathrm{~ns}$ & $31.60 \mathrm{~ns}$ & $<40$ & 40 to 60 & $>60$ \\
\hline & \multicolumn{9}{|c|}{$\mathrm{mg} \mathrm{kg}^{-1}$} \\
\hline $\bar{B}$ & $0.11 \mathrm{~ns}$ & $0.08 \mathrm{~ns}$ & $0.10 \mathrm{~ns}$ & $0.09 \mathrm{~ns}$ & $0.11 \mathrm{~ns}$ & $0.14 \mathrm{~ns}$ & $<0.2$ & 0.3 to 0.5 & $>0.5$ \\
\hline $\mathrm{Cu}$ & $1.83 \mathrm{bc}$ & $1.87 \mathrm{bc}$ & $1.23 \mathrm{c}$ & $2.40 \mathrm{~b}$ & $2.15 b c$ & $3.70 \mathrm{a}$ & $<0.4$ & 0.5 to 0.8 & $>0.8$ \\
\hline $\mathrm{Fe}$ & $96.90 \mathrm{~b}$ & $76.10 \mathrm{~b}$ & $58.60 \mathrm{~b}$ & $219.00 \mathrm{a}$ & $229.10 \mathrm{a}$ & $220.30 \mathrm{a}$ & $<4$ & 4 to 12 & $>12$ \\
\hline $\mathrm{Mn}^{* *}$ & $10.00 \mathrm{~b}$ & $7.30 \mathrm{bc}$ & $3.70 \mathrm{c}$ & $34.40 \mathrm{a}$ & $42.10 \mathrm{a}$ & $44.70 \mathrm{a}$ & $<1.9$ & 1.9 to 5 & $>5$ \\
\hline $\mathrm{Zn}$ & $2.43 \mathrm{ab}$ & $2.57 \mathrm{ab}$ & $1.97 \mathrm{~b}$ & $3.23 \mathrm{ab}$ & $3.30 \mathrm{ab}$ & $4.40 \mathrm{a}$ & $<1$ & 1 to 1.6 & $>1.6$ \\
\hline Mo & $17.20 \mathrm{~ns}$ & $16.10 \mathrm{~ns}$ & $17.80 \mathrm{~ns}$ & $15.50 \mathrm{~ns}$ & $18.90 \mathrm{~ns}$ & $16.30 \mathrm{~ns}$ & nd & nd & nd \\
\hline
\end{tabular}

Equal lowercase letters on the same line do not differ significantly at 5\% level by the Tukey's test. SB: sum of bases; V: base saturation; C: organic carbon; CEC: cation exchange capacity. *Parameter that did not present normal distribution and was used in the non-parametric Kruskal-Wallis test; ns: not significant; Treatments: 1: no fertilization; 2: conventional fertilization recommended for passion fruit based on soil analysis; 3: conventional organic fertilization; 4: organic fertilizer enriched with biotite schist; 5 : conventional fertilization with replacement of the potassium source; 6: chemical fertilizer only. **Soil fertility levels for passion fruit in the Cerrado, de Resende et al. (2008), where L (low), $\mathrm{M}$ (medium), A (adequate), nd (not determined).

In terms of production, no variation among treatments was observed (Table 2). The total number of fruits per plant ranged from 11 to 53, and these fruits had mass ranging from 32 to $127 \mathrm{~g}$, generating total mass per plant ranging from $0.56 \mathrm{~kg}$ to $5.15 \mathrm{~kg}$.

The multivariate analysis evidenced the contribution of different fertilizations on the physicochemical properties of the pulp, texture and color of fruits stored at ambient temperature (Figure 1A) and under refrigeration (1B). Treatments $\mathrm{T} 1$ and $\mathrm{T} 4$ showed similar data dispersion patterns in ambient and refrigerated storage, indicating that the nutrient balance in these fertilizations contributed to the stability of the analyzed characteristics. Different situation was observed in relation to $\mathrm{T} 3$, which showed the influence of fertilization on the behavior of physical and physicochemical variables of fruits evidenced by the type of storage. The other treatments also promoted changes in fruit properties, but with less impact on overall characteristics.
According to Figures $1 \mathrm{C}$ and D, samples had similar behavior in the two types of storage, with increase in data dispersion over time. The result is suggestive of within-sample variations but not noticeable prior to storage (Figure 2A). This variation may be the result of differences in the fruit maturation stage and/or genetic variability of the evaluated plant population. 


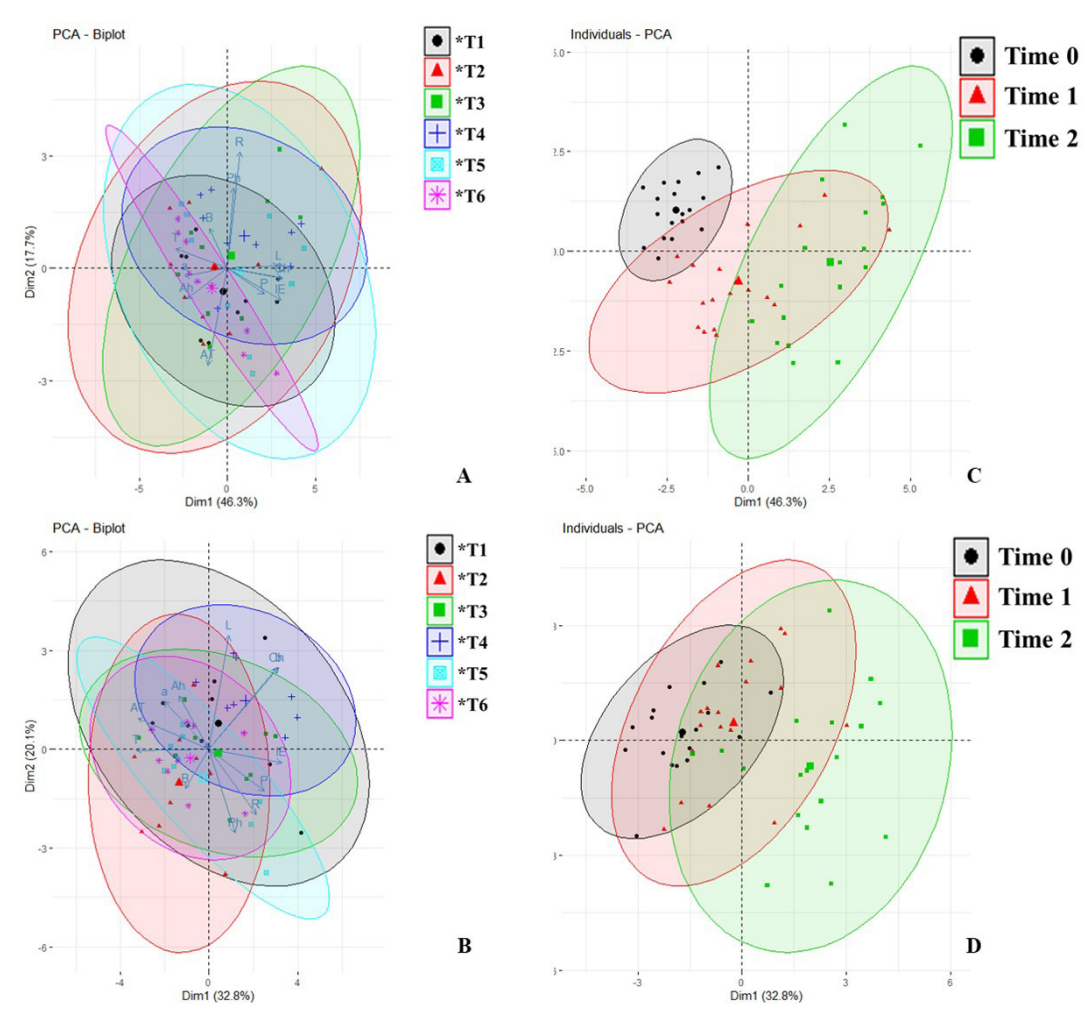

Figure 1. Correlation between fertilization and physicochemical properties, color and texture of Passiflora cincinnata BRS SF fruits stored under ambient (A) and refrigeration conditions (B); dispersion of samples stored under ambient (C) and refrigeration conditions (D); PCA: Principal Component Analysis; Dim: Dimension. Time 0: before storage; Time 1: 30 days of storage; Time 2: 60 days of storage. *T: Type of fertilization (Treatment): T1: No fertilization; T2: Conventional fertilization recommended for passion fruit (chemical fertilization supplemented with organic matter); T3: Organic fertilization; T4: Organic fertilization with biotite schist; T5: Chemical fertilization with biotite schist; T6: Chemical fertilization.
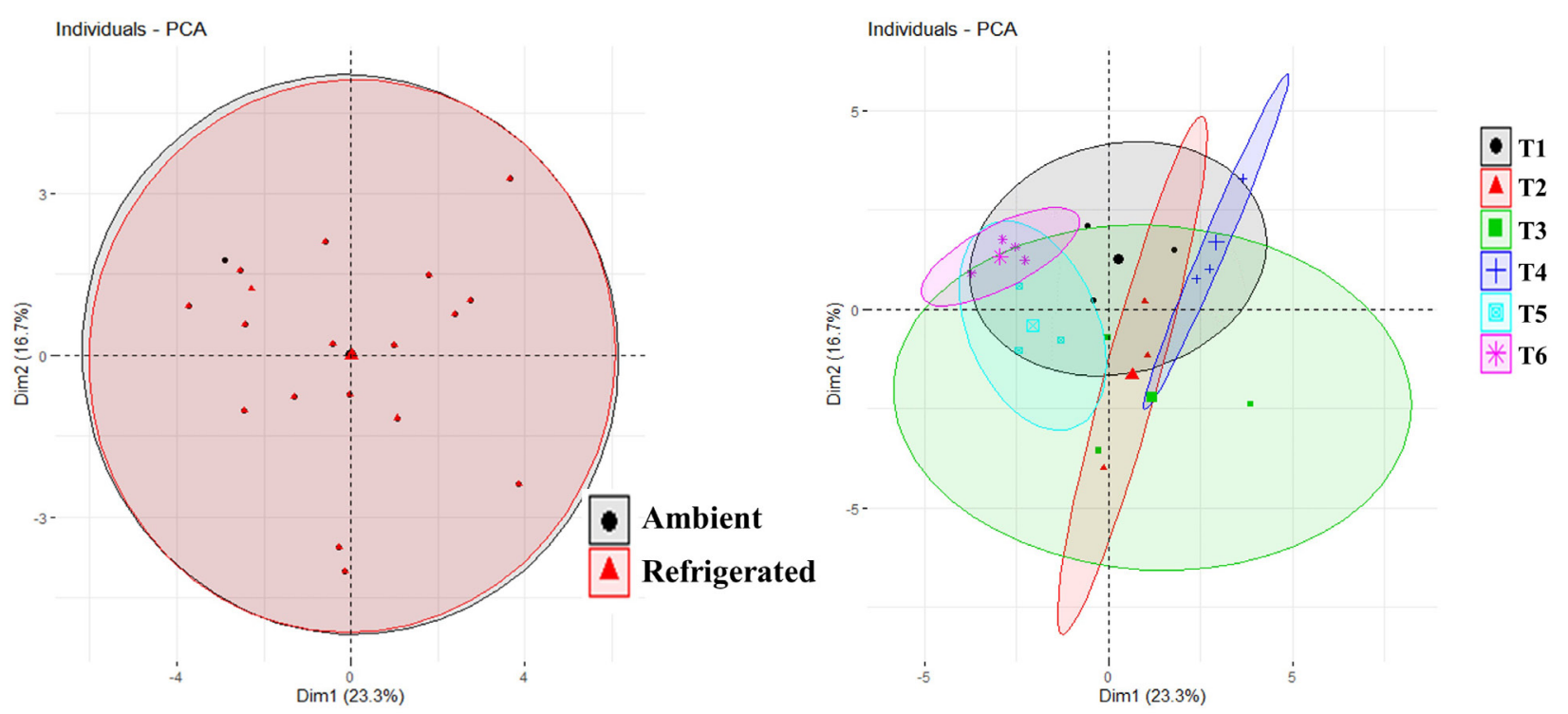

Figure 2. Uniformity of samples before storage (A) given by the influence of fertilizers on the presence of nutrients in leaves, physicochemical properties of the pulp, color and texture of Passiflora cincinnata BRS SF fruits (B). PCA: Principal Component Analysis; Dim: Dimension. T: Treatment. T1: No fertilization; T2: Conventional fertilization; T3: Organic fertilization; T4: Organic fertilization plus Biotite Schist; T5. Chemical fertilization with Biotite Schist; T6: Chemical fertilization. 
Figure 2B shows the dispersions of the joint of leaf nutrition, pulp physicochemical, color and texture evaluation of fresh fruits as a function of type of fertilization. The correlation showed that each treatment contributed differently to the overall characteristics, where $\mathrm{T} 2$ was close to $\mathrm{T} 4$, similarly to $\mathrm{T} 5$ in relation to $\mathrm{T} 6$.
There was an evolution of the overall characteristics and presence of minerals in leaves during the storage of fruits obtained with different fertilizations (Figure 3).
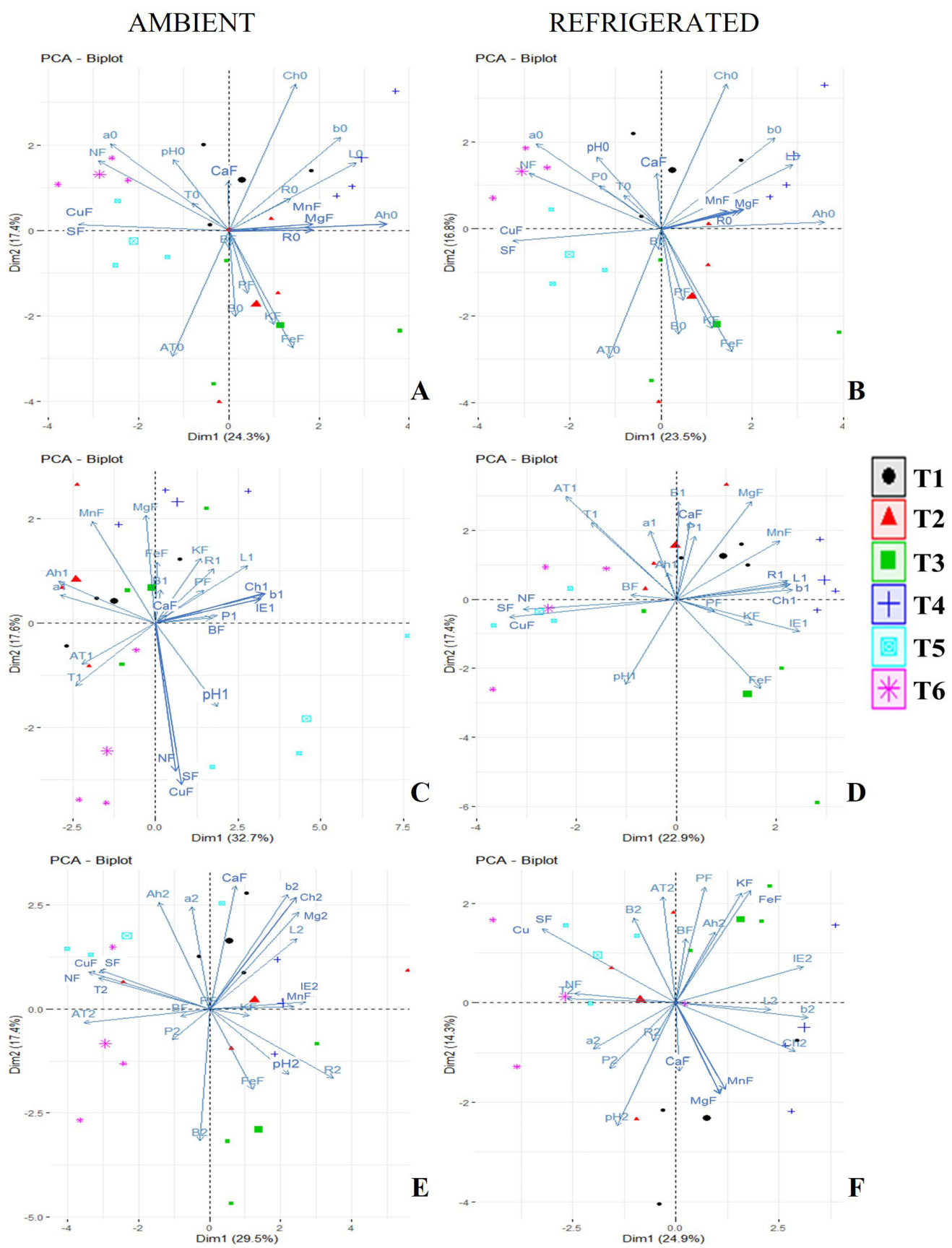

Figure 3. Correlation between mineral contents of leaves (Nitrogen (NF), Phosphorus (PF), Potassium (KF), Calcium (CaF), Magnesium (MgF), Sulfur (SF), Iron (FeS), Boron (BF), Copper (CuF), Manganese (MnF)); pulp physicochemical properties ( $\mathrm{pH}$, Titratable Acidity (TA) and Ratio), color (L*, $\mathrm{a}^{*}, \mathrm{~b}^{*}$, Browning Increment (IE), Chroma $(\mathrm{Ch})$, Hue Angle (Ah)) and texture (T) of Passiflora cincinnata BRS SF fruits stored at ambient temperature and under refrigeration over time (day zero (0), 30 days (1) and 60 days (2)), produced with different types of fertilization: T1: No fertilization; T2: Conventional fertilization recommended for passion fruit; T3: Organic fertilization; T4: Organic fertilization plus Biotite Schist; T5: Chemical fertilization plus Biotite Schist; T6: Chemical fertilization. Before ambient (A) and refrigerated (B) storage. At 30 days at ambient temperature (C) and under refrigeration (D) and at 60 days at ambient temperature (E) and without refrigeration (F). Symbols highlighted in the graph indicate the centroids of corresponding treatments. PCA: Principal Component Analysis; Dim: Dimension. 
Fresh fruits showed direct correlation of pulp $\mathrm{pH}, \mathrm{a}^{*}$ value (associated with fruit color), Fresh Mass Loss (FML) and texture with the presence of $\mathrm{N}$ and $\mathrm{Ca}$, and with $\mathrm{Cu}$ and $\mathrm{S}$, with greater participation of the first two elements. In addition, there was inverse correlation of these variables with the presence of $\mathrm{Fe}, \mathrm{K}, \mathrm{B}$ and $\mathrm{P}$ and with $\mathrm{Mg}$ and $\mathrm{Mn}$ (Figures $1 \mathrm{~A}$ and $\mathrm{B}$ ). The Angle Hue, $L^{*}, b^{*}$ values and more distantly those of Chroma (characteristics associated with fruit color) were inversely correlated with the presence of $\mathrm{Fe}, \mathrm{K}$ and $\mathrm{P}$ and Soluble Solids (SS) and directly correlated with the presence of $\mathrm{Mn}, \mathrm{Mg}$ and Ratio. Ratio was inversely correlated with titratable acidity, which in turn showed direct correlation with the presence of $\mathrm{P}, \mathrm{K}$ and $\mathrm{Fe}$.

At 30 days of storage, (Figures $3 \mathrm{C}$ and D), the direct correlation of $\mathrm{pH}$ with $\mathrm{N}, \mathrm{S}$ and $\mathrm{Cu}$ under ambient and refrigeration conditions persisted (Figure $3 \mathrm{~A}$ and $\mathrm{B})$, a situation that also occurred, with less intensity, in refrigerated storage at 60 days (Figure 3F). However, the pattern reversed for storage at ambient temperature (Figure 3E).

Likewise, maintenance of the $\mathrm{pH}$ standard of fruits was verified before storage (Figure $3 \mathrm{~A}$ and $\mathrm{B}$ ) of $\mathrm{Fe}, \mathrm{K}$ and $\mathrm{P}$ in storage for 30 days (Figure $3 \mathrm{C}$ and $\mathrm{D}$ ) and in refrigerated storage for 60 days (Figure 3F), and under ambient conditions, the change was inverse with direct correlation (Figure 3E). In relation to $\mathrm{Mg}$ and $\mathrm{Mn}$, inverse correlation with the $\mathrm{pH}$ of fruits before storage for 30 days was observed in both ambient and refrigeration conditions, with change in the profile at 60 days in both storage conditions (Figure 3E and F).

At 30 days, the texture started to have direct correlation with titratable acidity (TA), a situation also verified at 60 days in ambient and refrigeration conditions, with direct correlation between texture and presence of nitrogen in leaves. Similar behavior was observed in relation to the Hue Angle, with regard to TA (Figure 3F). TA presented variations in the correlation with minerals $\mathrm{K}, \mathrm{P}, \mathrm{Fe}$, with inversion of the direct correlation (Figures $3 \mathrm{~A}$ and $\mathrm{B}$ ) to inverse at 30 days compared to refrigerated storage and ambient storage at 60 days (Figures 3C, D and $\mathrm{E})$.

Regarding SS, positive correlation was observed between fruit pulp sweetness after harvest with the presence of $\mathrm{K}, \mathrm{Fe}$ and $\mathrm{P}$ in leaves (Figure $3 \mathrm{~A}$ and $\mathrm{B}$ ), a trend that persists after 30 days of storage at ambient temperature (Figure 3E), and at 60 days, regardless of type of storage. In relation to the presence of $\mathrm{Mg}$ and $\mathrm{Mn}$, weak correlation was observed in fruits before storage (Figure 3A and B). At 30 days, the trend evolved to direct contribution, regardless of type of storage (Figure $3 \mathrm{C}$ and D), with inversion of behavior at 60 days in both ambient and refrigerated storage (Figure $3 \mathrm{E}$ and F). The SS of fresh fruits stored for 30 and 60 days was inversely correlated with $\mathrm{pH}$, to a greater or lesser degree, except for ambient storage at 60 days (Figure 3E). Similarly, SS was also inversely correlated to a greater or lesser degree with the presence of $\mathrm{N}, \mathrm{S}$ and $\mathrm{Cu}$ in leaves, with the exception of refrigerated storage for 60 days (Figure $3 \mathrm{~F}$ ).

The average $\mathrm{pH}$ value of $P$. cincinnata pulp before storage was 2.83 without significant variations due to the type of fertilization. However, fertilizations affected the $\mathrm{pH}$ of pulps stored with and without refrigeration (Table 3), which varied between 2.56 and 3.00 in storage under ambient conditions and under refrigerated conditions between 2.74 and 2.98. Fruits from treatments organic fertilization enriched with biotite schist (T4), conventional fertilization with replacement of the soluble potassium source by biotite schist (T5) and chemical fertilization only (T6) stored under ambient conditions presented reduction in $\mathrm{pH}$ values (Table 3 ).

These values fit data established by the identity and quality MAPA standards for passion fruit pulp (Passiflora edulis Sims.), which recommends minimum $\mathrm{pH}$ value of 2.70 and maximum $\mathrm{pH}$ of 3.80 (BRAZIL, 2000). The fluctuation in $\mathrm{pH}$ values in the same treatments during storage may have occurred due to the specific characteristics of each sample, as shown by the correlation with nutrients present in leaves, and the storage of fruits at refrigerated temperature is the most recommended for the stability of this variable. 
Table 3. Mean $\mathrm{pH}$, titratable acidity, Ratio and texture values of Passiflora cincinnata BRS Sertão Forte fruits produced with different fertilizations and stored under ambient and refrigeration conditions for 60 days.

\begin{tabular}{|c|c|c|c|c|c|c|c|}
\hline \multirow[b]{2}{*}{ Ad } & \multirow[b]{2}{*}{ CA (days) } & \multicolumn{2}{|c|}{$\mathrm{pH}$} & \multicolumn{4}{|c|}{ Titratable acidity (\%) } \\
\hline & & 0 & 30 & 60 & 0 & 30 & 60 \\
\hline \multirow{2}{*}{ T1 } & A & $2.79 \mathrm{aA}$ & $2.62 \mathrm{bA}$ & $2.68 \mathrm{aA}$ & $4.99 \mathrm{aB}$ & $5.91 \mathrm{aA}$ & $4.83 \mathrm{bB}$ \\
\hline & $\mathrm{R}$ & $2.79 \mathrm{aA}$ & $2.80 \mathrm{abA}$ & $2.92 \mathrm{aA}$ & $4.99 \mathrm{aA}$ & $5.04 \mathrm{abcA}$ & $4.37 \mathrm{bA}$ \\
\hline \multirow{2}{*}{$\mathrm{T} 2$} & A & $2.75 \mathrm{aA}$ & $2.56 \mathrm{bA}$ & $2.72 \mathrm{aA}$ & $5.02 \mathrm{aB}$ & $5.82 \mathrm{abA}$ & $4.67 \mathrm{bB}$ \\
\hline & $\mathrm{R}$ & $2.75 \mathrm{aA}$ & $2.78 \mathrm{abA}$ & $2.83 \mathrm{aA}$ & $5.02 \mathrm{aA}$ & $5.34 \mathrm{abcA}$ & $4.75 \mathrm{bA}$ \\
\hline \multirow{2}{*}{$\mathrm{T} 3$} & A & $2.75 \mathrm{aB}$ & $2.65 \mathrm{bB}$ & $3.00 \mathrm{aA}$ & $5.23 \mathrm{aA}$ & $5.58 \mathrm{abcA}$ & $4.36 \mathrm{bB}$ \\
\hline & $\mathrm{R}$ & $2.75 \mathrm{aA}$ & $2.87 \mathrm{abA}$ & $2.81 \mathrm{aA}$ & $5.23 \mathrm{aA}$ & $4.51 \mathrm{cA}$ & $4.63 \mathrm{bA}$ \\
\hline \multirow{2}{*}{$\mathrm{T} 4$} & A & $2.87 \mathrm{aA}$ & $2.60 \mathrm{bB}$ & $2.67 \mathrm{aAB}$ & $4.46 \mathrm{aA}$ & $5.10 \mathrm{abcA}$ & $4.38 \mathrm{bA}$ \\
\hline & $\mathrm{R}$ & $2.87 \mathrm{aA}$ & $2.74 \mathrm{abA}$ & $2.83 \mathrm{aA}$ & $4.46 \mathrm{aA}$ & $4.76 \mathrm{bcA}$ & $4.24 \mathrm{bA}$ \\
\hline \multirow{2}{*}{ T5 } & A & $2.88 \mathrm{aA}$ & $2.82 \mathrm{aA}$ & $2.67 \mathrm{aB}$ & $5.00 \mathrm{aA}$ & $5.39 \mathrm{abcA}$ & $5.08 \mathrm{bA}$ \\
\hline & $\mathrm{R}$ & $2.88 \mathrm{aA}$ & $2.88 \mathrm{abA}$ & $2.98 \mathrm{aA}$ & $5.00 \mathrm{aAB}$ & $5.18 \mathrm{abcA}$ & $4.34 \mathrm{bB}$ \\
\hline \multirow{2}{*}{ T6 } & A & $2.91 \mathrm{aA}$ & $2.73 \mathrm{bAB}$ & $2.65 \mathrm{aB}$ & $4.97 \mathrm{aB}$ & $5.47 \mathrm{abcB}$ & $6.64 \mathrm{aA}$ \\
\hline & $\mathrm{R}$ & $2.91 \mathrm{aA}$ & $2.88 \mathrm{abA}$ & $2.84 \mathrm{aA}$ & $4.97 \mathrm{aA}$ & $5.09 \mathrm{abcA}$ & $4.86 \mathrm{bA}$ \\
\hline \multirow[t]{2}{*}{ F } & & \multicolumn{2}{|c|}{2.3554} & \multicolumn{3}{|c|}{2.4381} & \\
\hline & & \multicolumn{2}{|c|}{ Ratio } & \multicolumn{3}{|c|}{ Texture $(\mathrm{N})$} & \\
\hline $\mathrm{Ad}$ & CA (days) & 0 & 30 & 60 & 0 & 30 & 60 \\
\hline \multirow{2}{*}{$\mathrm{T} 1$} & A & $2.12 \mathrm{aA}$ & $1.81 \mathrm{aA}$ & $2.10 \mathrm{bcdA}$ & $31.1 \mathrm{bA}$ & $17.0 \mathrm{eB}$ & $7.7 \mathrm{eC}$ \\
\hline & $\mathrm{R}$ & $2.12 \mathrm{aA}$ & $2.13 \mathrm{aA}$ & $2.49 \mathrm{abA}$ & $31.1 \mathrm{bA}$ & $25.1 \mathrm{cB}$ & $17.0 \mathrm{bC}$ \\
\hline \multirow{2}{*}{$\mathrm{T} 2$} & A & $2.30 \mathrm{aA}$ & $1.89 \mathrm{aB}$ & $2.32 \mathrm{abcA}$ & $34.7 \mathrm{aA}$ & $21.5 \mathrm{~dB}$ & $9.4 \mathrm{dC}$ \\
\hline & $\mathrm{R}$ & $2.30 \mathrm{aA}$ & $2.23 \mathrm{aA}$ & $2.52 \mathrm{abA}$ & $34.7 \mathrm{aA}$ & $28.5 \mathrm{bB}$ & $25.3 \mathrm{aC}$ \\
\hline \multirow{2}{*}{ T3 } & A & $2.14 \mathrm{aB}$ & $1.82 \mathrm{aB}$ & $2.57 \mathrm{abA}$ & $23.6 \mathrm{cA}$ & $13.6 \mathrm{fB}$ & $6.1 \mathrm{eC}$ \\
\hline & $\mathrm{R}$ & $2.14 \mathrm{aA}$ & $2.24 \mathrm{aA}$ & $2.40 \mathrm{abA}$ & $23.6 \mathrm{cA}$ & $15.7 \mathrm{eB}$ & $9.7 \mathrm{dC}$ \\
\hline \multirow{2}{*}{$\mathrm{T} 4$} & A & $2.43 \mathrm{aA}$ & $2.28 \mathrm{aA}$ & $2.43 \mathrm{abA}$ & $25.8 \mathrm{cA}$ & $19.0 \mathrm{eB}$ & $10.1 \mathrm{dC}$ \\
\hline & $\mathrm{R}$ & $2.43 \mathrm{aA}$ & $2.33 \mathrm{aA}$ & $2.38 \mathrm{abA}$ & $25.8 \mathrm{cA}$ & $21.4 \mathrm{~dB}$ & $9.9 \mathrm{dC}$ \\
\hline \multirow{2}{*}{ T5 } & A & $2.29 \mathrm{aA}$ & $2.05 \mathrm{aAB}$ & $1.81 \mathrm{cdB}$ & $24.2 \mathrm{cA}$ & $11.0 \mathrm{fB}$ & $11.4 \mathrm{cB}$ \\
\hline & $\mathrm{R}$ & $2.29 \mathrm{aAB}$ & $2.00 \mathrm{aB}$ & $2.64 \mathrm{aA}$ & $24.2 \mathrm{cA}$ & $23.7 \mathrm{cA}$ & $13.9 \mathrm{cB}$ \\
\hline \multirow{2}{*}{ T6 } & A & $2.15 \mathrm{aA}$ & $2.04 \mathrm{aAB}$ & $1.67 \mathrm{~dB}$ & $34.0 \mathrm{aA}$ & $29.4 \mathrm{bB}$ & $11.2 \mathrm{cC}$ \\
\hline & $\mathrm{R}$ & $2.15 \mathrm{aA}$ & $2.16 \mathrm{aA}$ & $2.21 \mathrm{abcA}$ & $34.0 \mathrm{aA}$ & $33.0 \mathrm{aA}$ & $26.7 \mathrm{aB}$ \\
\hline
\end{tabular}

Equal lowercase letters in the same column and uppercase in the line do not differ significantly at 5\% level in Tukey's test. CA: storage condition; A: Ambient; R: Refrigerated; T1: no fertilization; T2: conventional fertilization recommended for passion fruit based on soil analysis; T3: conventional organic fertilization; T4: organic fertilizer enriched with biotite schist; T5: conventional fertilization with replacement of the potassium source; T6: chemical fertilization only.

The titratable acidity values ranged from $4.36 \%$ to $6.64 \%$ at ambient storage, and $4.24 \%$ and $5.34 \%$ at refrigerated storage, with values above minimum values established (2.5\%) by the Brazilian legislation for passion fruit (Passiflora edulis Sims) (BRAZIL, 2000). D'Abadia et al. (2020) also obtained acidity values (4.5\% to 5.3\%), being in the same range observed in the present study for BRS Sertão Forte fruits harvested after 60 days from anthesis.

In all treatments, with the exception of refrigerated $\mathrm{T} 3$ and ambient T6, there was increase in values up to 30 days of storage with subsequent reduction up to 60 days of storage (Table 3 ). This behavior may be related to the ripening point of fruits, where the decrease in titratable acidity values is justified by the increase in the respiratory activity of fruits, which can use organic acids as substrate.
Fruits produced with organic fertilization stored under refrigeration showed reduction in acidity values up to 30 days with subsequent increase. On the other hand, those from the chemical fertilization treatment kept under ambient conditions presented increase in acidity values throughout the storage, reaching $6.64 \%$ at 60 days. This sample showed low pH value (Table 3 ), significant reduction in Ratio and texture values (Table 3) and considerable fresh mass loss (Table 4) in the same period of analysis. 
Table 4. Mean fresh mass loss, browning increment, Chroma and hue angle values of Passiflora cincinnata BRS Sertão Forte fruits produced with different fertilizations and stored under ambient and refrigeration conditions for 60 days.

\begin{tabular}{|c|c|c|c|c|c|c|c|}
\hline \multirow[b]{2}{*}{ Ad } & \multirow[b]{2}{*}{ CA (days) } & \multicolumn{2}{|c|}{ Fresh mass loss $(\%)$} & \multicolumn{3}{|c|}{ Browning increment (IE) } & \multirow[b]{2}{*}{60} \\
\hline & & 0 & 30 & 60 & 0 & 30 & \\
\hline \multirow{2}{*}{$\mathrm{T} 1$} & A & $0.00 \mathrm{aC}$ & $6.87 \mathrm{bB}$ & $17.59 \mathrm{bA}$ & $0.00 \mathrm{aC}$ & $11.22 \mathrm{cB}$ & $17.09 \mathrm{abA}$ \\
\hline & $\mathrm{R}$ & $0.00 \mathrm{aC}$ & $1.88 \mathrm{cB}$ & $5.51 \mathrm{dA}$ & $0.00 \mathrm{aC}$ & $11.41 \mathrm{cB}$ & $13.17 \mathrm{cA}$ \\
\hline \multirow{2}{*}{$\mathrm{T} 2$} & A & $0.00 \mathrm{aC}$ & $5.04 \mathrm{bB}$ & $11.45 \mathrm{cA}$ & $0.00 \mathrm{aC}$ & $10.93 \mathrm{cB}$ & $18.93 \mathrm{aA}$ \\
\hline & $\mathrm{R}$ & $0.00 \mathrm{aC}$ & $1.89 \mathrm{cB}$ & $3.62 \mathrm{dA}$ & $0.00 \mathrm{aC}$ & $8.13 \mathrm{~dB}$ & $10.38 \mathrm{dA}$ \\
\hline \multirow{2}{*}{$\mathrm{T} 3$} & A & $0.00 \mathrm{aC}$ & $9.00 \mathrm{aB}$ & $27.26 \mathrm{aA}$ & $0.00 \mathrm{aC}$ & $14.80 \mathrm{aB}$ & $19.75 \mathrm{aA}$ \\
\hline & $\mathrm{R}$ & $0.00 \mathrm{aC}$ & $1.57 \mathrm{cB}$ & $3.17 \mathrm{dA}$ & $0.00 \mathrm{aC}$ & $10.81 \mathrm{cB}$ & $16.02 \mathrm{bA}$ \\
\hline \multirow{2}{*}{ T4 } & $\mathrm{A}$ & $0.00 \mathrm{aC}$ & $5.30 \mathrm{bB}$ & $12.42 \mathrm{cA}$ & $0.00 \mathrm{aC}$ & $13.25 \mathrm{bB}$ & $18.52 \mathrm{aA}$ \\
\hline & $\mathrm{R}$ & $0.00 \mathrm{aB}$ & $1.57 \mathrm{cA}$ & $2.97 \mathrm{dA}$ & $0.00 \mathrm{aC}$ & $10.09 \mathrm{cB}$ & $14.71 \mathrm{bA}$ \\
\hline \multirow{2}{*}{$\mathrm{T} 5$} & A & $0.00 \mathrm{aC}$ & $8.86 \mathrm{aB}$ & $29.81 \mathrm{aA}$ & $0.00 \mathrm{aC}$ & $15.51 \mathrm{aB}$ & $19.83 \mathrm{aA}$ \\
\hline & $\mathrm{R}$ & $0.00 \mathrm{aC}$ & $1.88 \mathrm{cB}$ & $3.67 \mathrm{cA}$ & $0.00 \mathrm{aC}$ & $7.67 \mathrm{~dB}$ & $12.15 \mathrm{cA}$ \\
\hline \multirow{2}{*}{ T6 } & A & $0.00 \mathrm{aC}$ & $4.66 \mathrm{bB}$ & $9.35 \mathrm{cA}$ & $0.00 \mathrm{aC}$ & $11.03 \mathrm{cB}$ & $19.27 \mathrm{aA}$ \\
\hline & $\mathrm{R}$ & $0.00 \mathrm{aC}$ & $1.30 \mathrm{cB}$ & $5.58 \mathrm{dA}$ & $0.00 \mathrm{aB}$ & $8.00 \mathrm{dA}$ & $9.14 \mathrm{dA}$ \\
\hline \multirow[t]{2}{*}{ F } & & \multicolumn{2}{|c|}{1.7952} & \multicolumn{3}{|c|}{1.9632} & \\
\hline & & \multicolumn{2}{|c|}{ Chroma } & \multicolumn{3}{|c|}{ Hue Angle } & \\
\hline Ad & CA (days) & 0 & 30 & 60 & 0 & 30 & 60 \\
\hline \multirow{2}{*}{$\mathrm{T} 1$} & A & $24.32 \mathrm{aB}$ & $26.40 \mathrm{aB}$ & $34.13 \mathrm{aA}$ & $91.28 \mathrm{aA}$ & $91.20 \mathrm{aA}$ & $91.34 \mathrm{aA}$ \\
\hline & $\mathrm{R}$ & $24.32 \mathrm{aA}$ & $26.20 \mathrm{aA}$ & $26.66 \mathrm{aA}$ & $91.28 \mathrm{aA}$ & $91.13 \mathrm{aA}$ & $90.59 \mathrm{abA}$ \\
\hline \multirow{2}{*}{$\mathrm{T} 2$} & A & $21.48 \mathrm{aB}$ & $22.90 \mathrm{aB}$ & $33.30 \mathrm{aA}$ & $91.29 \mathrm{aA}$ & $91.31 \mathrm{aA}$ & $81.27 \mathrm{cdB}$ \\
\hline & $\mathrm{R}$ & $21.48 \mathrm{aA}$ & $22.63 \mathrm{aA}$ & $23.62 \mathrm{aA}$ & $91.29 \mathrm{aA}$ & $91.31 \mathrm{aA}$ & $91.31 \mathrm{aA}$ \\
\hline \multirow{2}{*}{ T3 } & A & $23.58 \mathrm{aB}$ & $25.98 \mathrm{aB}$ & $30.15 \mathrm{aA}$ & $91.31 \mathrm{aA}$ & $91.32 \mathrm{aA}$ & $87.55 \mathrm{eB}$ \\
\hline & $\mathrm{R}$ & $23.58 \mathrm{aA}$ & $24.48 \mathrm{aA}$ & $24.97 \mathrm{aA}$ & $91.31 \mathrm{aA}$ & $91.27 \mathrm{aA}$ & $91.28 \mathrm{aA}$ \\
\hline \multirow{2}{*}{$\mathrm{T} 4$} & A & $26.29 \mathrm{aB}$ & $29.71 \mathrm{aB}$ & $37.13 \mathrm{aA}$ & $91.32 \mathrm{aA}$ & $91.25 \mathrm{aA}$ & 87.55 bcdB \\
\hline & $\mathrm{R}$ & $26.29 \mathrm{aB}$ & $28.79 \mathrm{aAB}$ & $30.31 \mathrm{aA}$ & $91.32 \mathrm{aA}$ & $91.33 \mathrm{aA}$ & $91.35 \mathrm{aA}$ \\
\hline \multirow{2}{*}{$\mathrm{T} 5$} & A & $22.95 \mathrm{aB}$ & $32.52 \mathrm{aA}$ & $33.24 \mathrm{aA}$ & $91.26 \mathrm{aA}$ & $91.18 \mathrm{aA}$ & $86.97 \mathrm{bB}$ \\
\hline & $\mathrm{R}$ & $22.95 \mathrm{aA}$ & $22.92 \mathrm{aA}$ & $24.21 \mathrm{aA}$ & $91.26 \mathrm{aA}$ & $91.27 \mathrm{aA}$ & 90.43 abcA \\
\hline \multirow{2}{*}{ T6 } & A & $23.46 \mathrm{aB}$ & $25.52 \mathrm{aB}$ & $30.96 \mathrm{aA}$ & $91.25 \mathrm{aA}$ & $91.29 \mathrm{aA}$ & $84.03 \mathrm{deB}$ \\
\hline & $\mathrm{R}$ & $23.46 \mathrm{aA}$ & $25.17 \mathrm{aA}$ & $25.44 \mathrm{aA}$ & $91.25 \mathrm{aA}$ & $91.28 \mathrm{aA}$ & $90.82 \mathrm{abA}$ \\
\hline $\mathrm{F}$ & & & 0.9708 & & & 7.4689 & \\
\hline
\end{tabular}

Equal lowercase letters in the same column and uppercase in the line do not differ significantly at $5 \%$ level in Tukey's test. CA: storage condition; A: Ambient; R: Refrigerated; T1: no fertilization; T2: conventional fertilization recommended for passion fruit based on soil analysis; T3: conventional organic fertilization; T4: organic fertilizer enriched with biotite schist; T5: conventional fertilization with replacement of the potassium source; T6: chemical fertilization only.

There were no statistical differences regarding the soluble solids content (data not shown), both in relation to different fertilizations and in relation to storage time and condition. Soluble solids contents ranged from $9.07{ }^{\circ}$ Brix to $11.83^{\circ}$ Brix in fruits stored under ambient conditions and from $10.10^{\circ} \mathrm{Brix}$ to $11.90^{\circ} \mathrm{Brix}$ in those stored under refrigeration conditions. MAPA establishes minimum soluble solids content of $11 \%$ for Passiflora spp. fruit pulp (BRAZIL, 2000). Throughout the experiment, soluble solids contents were above or very close to the limit established for this variable.

Ratio values were between 1.67 and 2.64, close to values obtained by Santos et al. (2016) for fruits of the same species at different maturity stages, presenting Ratio values of 2.01 (almost ripe), 1.94 (ripe) and 2.11 (senescent). D'Abadia et al. (2020) obtained Ratio values between 2.2 and 2.7 for fruits of the parental population aged 60 days or more from anthesis.
Soon after harvest (day zero), fruits from treatments T2 (conventional fertilization recommended for passion fruit) and T6 (chemical fertilization only) presented the highest texture values, followed by $\mathrm{T} 1$ (no fertilization) and the other treatments (T3, T4 and T5), which showed no significant difference from each other (Table 3 ). The results indicate that fertilization may have influenced fruit texture, ensuring greater firmness in treatments with conventional chemical fertilization with and without organic matter, indicating that, despite the presence of potassium in the soil in treatments with biotite schist, the availability of the mineral was equivalent to that of treatment with cattle manure only. 
Texture values reduced in all treatments during the 60 days of storage with less reduction in fruits stored under refrigeration conditions. The storage temperature of fruits is a factor that influences pulp softening (COSTA et al., 2017) and under refrigeration, fruits present less texture reduction when compared to storage under ambient conditions, corroborating results of the present work.

Fruits stored under refrigeration showed lower fresh mass loss throughout the storage period, reaching maximum value of $5.58 \%$ in fruits grown with chemical fertilization only (T6) at 60 days of storage (Table 4). Passion fruits are considered wilted after loss of $8 \%$ of their initial visual standard mass, as it impairs the appearance of fruits and depreciates their commercial value (SILVA et al., 2009). For the present study, fruits kept under refrigeration would be accepted up to 60 days of storage. Under ambient conditions, up to 30 days, all treatments would also be accepted, with the exception of fruits from treatments $\mathrm{T} 3$ and $\mathrm{T} 5$ stored under ambient conditions, which presented FML values slightly above $8 \%$. The highest FML values occurred in fruits stored for 60 days at ambient temperature grown with organic (T3, $27.26 \%$ ) and chemical fertilizers with replacement of the potassium source by biotite schist (T5, 29.81\%). The mass loss in passion fruits results from the action of enzymes such as pectinases and cellulase, which degrade pectin chains (AGUIRRE et al., 2006) causing peel wrinkling and/or wilting, even with pulp in good consumption conditions (MANIWARA et al., 2015).

There was no statistical difference among treatments regarding luminosity (data not shown), with values ranging from 45.48 to 60.18 . This characteristic indicates the amount of light perceptible to the human eye in the same hue, that is, whether the color is lighter or darker, ranging from white to black (BOTELHO et al., 2015).

Most treatments kept under refrigeration presented values below or slightly above the maximum browning increment limit (IE > 10). Under refrigeration, the highest IE values were obtained after 60 days of storage for fruits produced with organic fertilization (T3) and organic fertilization with biotite schist (Table 4). Under ambient conditions, the highest IE values also occurred after 60 days of storage, with no statistical difference among treatments. The IE values of fruits of the present experiment ranged from zero to 19.83. However, undesirable browning that would justify the rejection of fruits was not visually observed. Considering the hue angle values (Table 4), it is possible to conclude that the highest IE values corresponded to the lowest hue angle values. Thus, variable IE was influenced by the color change of fruits from yellow to reddish.
There was no color variation in the different fertilization treatments, showing that the different nutrient sources did not influence the Chroma values of fruits (Table 4). During storage, fruits kept under refrigeration showed no significant variation in Chroma values, with the exception of fruits from treatment T4 (organic fertilization enriched with biotite schist), where significant increase in Chroma values was observed between the beginning (day zero) and end (60 days) of storage. On the other hand, fruits stored under ambient conditions showed significant increase in Chroma values throughout storage.

The Hue Angle values did not show significant variation in all treatments kept under refrigeration during the 60 days of storage, showing that the different types of fertilization did not influence this variable. However, there was correlation of this variable at 60 days of storage with the presence of minerals in leaves: $\mathrm{Mg}, \mathrm{Mn}, \mathrm{Fe}$, and to a lesser extent $\mathrm{P}, \mathrm{B}$ and $\mathrm{K}$.

Except for treatment T1, all treatments kept under ambient conditions showed significant variation at 60 days. In general, the Hue Angle values ranged from 81.27 to 91.35 , being close to $90^{\circ}$, which indicates that fruits present yellowish color (Table 4). These values indicate, therefore, that fruits stored under ambient conditions showed significant yellowish color tending to reddish color at 60 days of storage, except for the control treatment (T1) without fertilization.

Regarding physicochemical aspects, color and texture, correlations with soil minerals showed that the Chroma value of fruits stored at ambient temperature for 60 days presented correlations in order of magnitude from highest to lowest with $\mathrm{K}, \mathrm{P}, \mathrm{Ca}$ and $\mathrm{Mg}$ present in leaves. However, this correlation was not observed in fruits stored under ambient or refrigeration conditions for 30 days. The same behavior pattern was observed for the Hue Angle of non-stored fruits. In addition, direct correlation between the values of this variable and $\mathrm{K}, \mathrm{P}, \mathrm{Ca}$ and $\mathrm{Mg}$ contents present in leaves was observed, with greater participation of treatment 4 , as shown by the centroid positioning in the correlation (Figure 3). 


\section{Conclusions}

The greatest nutrient accumulations in plant tissues occurred with fertilization added of biotite schist soil remineralizer associated with protein synthesis $(\mathrm{N}, \mathrm{S}, \mathrm{B}$, $\mathrm{Cu}, \mathrm{Mn}, \mathrm{Zn})$.

Fruits from control treatments, which did not receive fertilization and organic fertilization enriched with biotite schist soil remineralizer $\left(3.5 \% \mathrm{~K}_{2} \mathrm{O}\right)$ presented higher postharvest quality regarding the physicochemical characteristics of pulp, texture and color of fruits kept under ambient and refrigeration conditions, indicating that the balance of nutrients in these fertilizations contributed to the stability of the analyzed characteristics.

Fruits stored under refrigeration conditions showed the best conservation results for their qualitative characteristics, considering that the postharvest shelf life of $P$. cincinnata fruits stored under refrigeration at $10^{\circ} \mathrm{C}$ is at least 60 days. Under ambient conditions, this period is of maximum 30 days.

\section{Acknowledgments}

The authors would like to thank the National Council for Scientific and Technological Development (CNPq) project No. 404847/2012-09 for the financial support, and the Brazilian Agricultural Research Company (Embrapa) for supporting the development of this research project.

\section{References}

AGUIRRE, O.M.; LOZANO, S.E.; OCAMPO, M.A.; TORRES, K.B.; MARTÍNEZ, A.D.V.; APARICIO, A.J. Cambios en la actividad de $\alpha$-amilasa, pectinmetilesterasa y poligalacturonasa durante la maduración del maracuyá amarillo (Passiflora edulis var. flavicarpa Degener). Interciencia, Caracas, v.31, p.728-733, 2006.

AOAC. Official methods of analysis. 19.ed. Arlington: Association of Official Analytical Chemists, 2019. 1141 p.

ARAÚJO, F.P.; MELO, N.F.; AIDAR, P. T.; YURI J.E.; FALEIRO, F.G. Cultivo de Passiflora cincinnata Mast. cv. BRS Sertão Forte. Petrolina: Embrapa, 2019. 12 p. (Circular técnica, 119).

BORGES, A.L. Nutrição mineral, calagem e adubação. In: LIMA, A. de A.; CUNHA, M. A.P. (ed.). Maracujá: produção e qualidade na passicultura. Cruz das Almas: Embrapa Mandioca e Fruticultura, 2004.
BOTELHO, F.M.; GRANELLA, S.J.; BOTELHO, S.C.C.; GARCIA, T.R.B. Influência da temperatura de secagem sobre as propriedades físicas dos grãos de soja. Engenharia na Agricultura, Viçosa, MG, v.23, n.3, p.212-219, 2015.

BRASIL. Regulamento Técnico Geral para Fixação dos Padrões de Identidade e Qualidade para Polpa de Fruta. Instrução Normativa ${ }^{\circ} 1$, de 07 de janeiro de 2000. Diário Oficial da União, Brasília, DF, 10 jan. 2000, Seção I, p.259.

CARMO, T.V.B.; MARTINS, L.S.S.; MUSSER, R.S.; SILVA, M.M.; SANTOS, J.P.O. Genetic diversity in accessions of Passiflora cincinnata Mast. based on morphoagronomic descriptors and molecular markers. Revista Caatinga, Mossoró, v.30, n.1, p.68-77, 2017.

COSTA,A.G.; PINTO, F.A.C.; BRAGA, R.A.; MOTOIKE, S.Y.; GRACIA, L.M.N. Relationship between biospeckle laser techniqueand firmness of Acrocomia aculeata fruits. Revista Brasileira de Engenharia Agrícola e Ambiental, Campina Grande, v.21, n.1, p.68-73, 2017.

CUNHA, M.C.; PASSOS, F.R.; MENDES, F.Q.; SILVA, S.A.; ALMEIDA, W.L.; NASSER, V.G. Extrato de própolis na conservação pós-colheita de maracujáamarelo. Interciencia, Caracas, v.42, n.5, p.320-323, 2017.

D'ABADIA, A.C.A.; COSTA, A.M.; FALEIRO, F.G.; RINALDI, M.M.; OLIVEIRA, L.L. MALAQUIAS, J.V. Determination of the maturation stage and characteristics of the fruits of two populations of Passiflora cincinnata Mast. Revista Caatinga, Mossoró, v.33, n.2, p.349-360, 2020.

EMBRAPA. Maracujá: BRS Sertão Forte (BRS SF). 2016. Disponível em: https://www.embrapa.br/busca-desolucoes-tecnologicas/-/produto-servico/3450/maracuja--brs-sertao-forte-brs-sf. Acesso em: 06 jun. 2020.

HUNTERLAB. Insight on color: CIE L* $a^{*} b^{*}$ color scale. Reston, 2008.

JUNQUEIRA, N.T.V.; ANSELMO, R.M.; PINTO, A.C.Q.; RAMOS, V.H.V.; PEREIRA, A.V.; NASCIMENTO, A.C. .Severidade da antracnose e perda de matéria fresca de frutos de dez procedências de maracujazeirodoce (Passiflora alata Dryander) em dois ambientes de armazenamento. Revista Brasileira de Fruticultura, Jaboticabal, v.25, n.1, p.71-73, 2003. 
LIMA, L.A.S.; REATTO, A.; ROIG, H.L.; MARTINS, E.S.; GOMES, M.P. Caracterização dos solos da Bacia do Sarandi. Planaltina, DF: Embrapa Cerrados, 2014. 47p. (Boletim de Pesquisa e Desenvolvimento, 318).

KIILL, L.H.P.; SIQUEIRA, K.M.M.; ARAÚJO, F.P.; TRIGO, S.P.M.; FEITOZA, E.A.; LEMOS, I.B. Biologia reprodutiva de Passiflora cincinnata Mast. (passifloraceae) na região de Petrolina (Pernambuco, Brazil). Oecologia Australis, Rio de Janeiro, v.14, n.1, p.115-127, 2010.

MANIWARA, P.; BOONYAKIAT, D.; POONLARP, P.B.; NATWICHAI, J.; NAKANO, K. Changes of postharvest quality in passion fruit (Passiflora edulis Sims) under modified atmosphere packaging conditions. International Food Research Journal, Malaysia, v.22, n.4, p.15961606, 2015.

MOURA, R.S. Nutritional status of yellow passion fruit submitted to nitrogen sources by fertigation. Comunicata Scientiae, Bom Jesus, v.8, n.4, p.562-569, 2017.

PIRES, M.M.; SÃO JOSÉ, A.R.; CONCEIÇÃO, A.O. Maracujá, avanços tecnológicos e sustentabilidade. Ilhéus: Ed. UESC, 2011. 232p.

R Core Team. R: a language and environment for statistical computing. Vienna: R Foundation for Statistical Computing,2018. Disponível em: https://www.R-project. org.

RESENDE, A.V.; SANZONOWICZ, C.; BRAGA, M.F.; FALEIRO, F. Manejo do Solo, nutrição e adubação do maracujazeiro-azedo na região do Cerrado. Planaltina (DF): Embrapa Cerrados, 2008. 33 p. (Documentos, 223)

RESENDE, A.V.; MACHADO, C.T.T.; MARTINS, E.S.; NASCIMENTO, M.T.; SENA M.C.; SILVA, L.C.R.; LINHARES, N.W. Rochas moídas como fontes de potássio para o milho em solo de cerrado. Planaltina (DF): Embrapa Cerrados, 2006.20 p. (Boletim de Pesquisa e Desenvolvimento, 162)

RINALDI, M.M.; DIANESE, A. de C.; COSTA, A.M. Avaliação do uso de cera de carnaúba na conservação póscolheita de frutos de Passiflora cincinnata cv. BRS Sertão Forte. Agrotrópica, Ilhéus, v.33, n.1, p.29-38, 2021.
RINALDI, M.M.; DIANESE, A. de C.; COSTA, A.M.; ASSIS, D.F. de O. da S.; OLIVEIRA, T.A.R. de; ASSIS, S.F. de O. Post-harvest conservation of Passiflora alata fruits under ambient and refrigerated condition. Ciência e Tecnologia de Alimentos, Campinas, v.1, p.1-8, 2019a.

RINALDI, M.M.; COSTA, A.M.; ASSIS, D.de O.da S.; FALEIRO, F.G.; JUNQUEIRA, N.T.V. Atmosfera modificada na conservação pós-colheita de frutos de Passiflora alata cv. BRS Mel do Cerrado (BRS MC). Agrotrópica, Ilhéus, v.31, p.185-196, 2019 b.

RINALDI, M.M.; COSTA, A.M.; DIANESE, A.deC.; SUSSEL, A.A.B. Recomendações de manuseio e conservação pós-colheita de frutos de Passiflora setacea e Passiflora alata. Planaltina (DF): Embrapa Cerrados, 2017. 4 p. (Comunicado Técnico, 179)

ROTILI, M.C.C.; COUTRO, S.; CELANT, V.M.; VORPAGEL, J.A.; BARP, F.K.; SALIBE, A.B.; BRAGA, G.C. Composição, atividade antioxidante e qualidade do maracujá amarelo durante armazenamento. Semina: Ciências Agrárias, Londrina, v.34, n.1, p.227-240, 2013a.

ROTILI, M.C.C.; VORPAGEL, J.A.; BRAGA, G.C.; KUHN, O.J.; SALIBE, A.B. Atividade antioxidante, composição química e conservação do maracujá-amarelo embalado com filme PVC. Revista Brasileira de Fruticultura, Jaboticabal, v.35, n.4, p.942-952, 2013 b.

SANTOS, J.L. Fisiologia da maturação de frutos e superação de dormência em sementes de maracujádo-mato (Passiflora cincinnata Mast.), 2018. 82f. Tese (Doutorado em Fitotecnia) - Faculdade de Agronomia, Universidade Estadual do Sudoeste da Bahia, Vitória da Conquista, 2018.

SANTOS, J.L.; MATSUMOTO, S.N.; OLIVEIRA, P.N.; OLIVEIRA, L. S.; SILVA, R.A. Morphophysiological analysis of passion fruit plants from different propagation methods and planting spacing. Revista Caatinga, Mossoró, v.29, n.2, p.305-312, 2016.

SENHOR, R.F.; SOUZA, P.A.; CARVALHO, J.N.; SILVAL, F.L.; SILVA, M.C. Fatores de pré e pós-colheita que afetam os frutos e hortaliças em pós-colheita. Revista Verde, Mossoró, v.4, n.3, p.13-21, 2009. 
SILVA, L.J.B.; SOUZA, M.L.; ARAÚJO NETO, S.E.; MORAIS, A.P. Revestimentos alternativos na conservação pós-colheita de maracujá-amarelo. Revista Brasileira de Fruticultura, Jaboticabal, v.31, p.995-1003, 2009.
SIEBRA, A.L.A.; OLIVEIRA, L.R.; MARTINS, A.O.B.P.B.; SIEBRA, D.C.; ALBUQUERQUE, R.S.; LEMOS, I.C.S.L.; DELMONDES, G.A.; TINTINO, S.R.; FIGUEREDO, F.G.; COSTA, J.G.M.; COUTINHO, H.D.M.; MENEZES, I.R.A.; FELIPE, C.F.B.; KERNTOPF, M.R. Potentiation of antibiotic activity by Passiflora cincinnata Mast. front of strains Staphylococcus aureus and Escherichia coli. Saudi Journal of Biological Sciences, Amsterdam, v.25, n.1, p.37-43, 2018. 